\title{
La gente no quiere pensar, la gente quiere ser fan
}

\author{
El ciudadano ilustre | Mariano Cohn, Gastón Duprat | 2016 \\ Verónica Nieto"
}

Universitat de Barcelona

Recibido: 20 de agosto 2018; aceptado: 17 de octubre 2018

\begin{abstract}
Resumen
A propósito de El ciudadano ilustre y la mediatización del autor como figura estrella y el fenómeno de la importancia del autor tanto más que la obra del escritor. La gente quiere ser fan. Además, el artículo explica brevemente las posturas estructuralistas de la crítica literaria, que a mediados del siglo XX postulaban la "muerte del autor" y el nacimiento de la teoría de la recepción, es decir, la importancia del lector y de la interpretación mucho más que de la autoría y la intencionalidad del autor. Sin embargo, el autor fue tomando protagonismo cada vez más, aunque lo haga fuera del texto. El autor deja de ser una función dentro del texto y cobra enorme importancia como persona de carne y hueso.
\end{abstract}

Palabras clave: autor | escritor | fan | teoría de la recepción | lector | crítica literaria

People do not want to think, people want to be a fan

\begin{abstract}
About El ciudadano ilustre and the mediatization of the author as a star figure and the phenomenon of the author's importance more than the writer's work. People want to be a fan. In addition, the article makes a brief explanation of the structuralism positions of literary criticism, which in the mid-twentieth century postulated the "death of the author" and the birth of the theory of reception, that is, the importance of the reader and interpretation much more than of authorship and intentionality of the author. However, the author was taking more and more prominence, although he does it outside the text. The author ceases to be a function within the text and becomes enormously important as a person of flesh and blood.
\end{abstract}

Key words: author | writer | fan | reception theory | reader | literary criticism

El ciudadano ilustre, película dirigida por Mariano Cohn y Gastón Duprat (2016), cuenta la historia de un escritor argentino, Daniel Mantovani (interpretado por Óscar Martínez), que gana el premio Nobel y cómo aquello le cambia la vida. Enseguida empiezan a invitarlo a infinidad de eventos y por supuesto que no puede asistir a todos. Sin embargo, hay uno que, a pesar de que no parece gran cosa, le atrae por razones personales: Salas, su pueblo natal, adonde no regresa desde hace cuarenta años y que Montovani utiliza como escenario de la mayoría de sus novelas, le acaba de nombrar "Ciudadano ilustre" y lo invita a acudir a la ceremonia. Si acepta, durante su estancia participará, además, en varios eventos, como formar parte del jurado de un premio de pintura, inaugurar su propio busto en una plaza e impartir unos seminarios sobre literatura, entre otras cosas. Montovani, cansado ya de sus apariciones públicas que parecen importar más que su obra, decide aceptar la invitación y viajar al pasado. Además, hace tanto que da conferencias que apenas tiene tiempo para escribir y sospecha que la experiencia será inspiradora. Volver a la geografía de su infancia, a los recuerdos, además de darse un paseo por el escenario de su propia ficción comienza a cobrar sentido desde el punto de vista del Montovani creador.

Ahora bien, rebobinemos un poco. En el discurso de la recepción del premio Nobel, Montovani dice que recibir dicho premio significa "el ocaso del artista", que "su obra coincide con el gusto de todos" o que se ha convertido en "el artista más cómodo". El artista debe interpelar, sacudir, ponerlo todo en cuestión. A continuación, la película se estructura en diversos capítulos a la manera de una novela, y al final de la película nos damos cuenta de que lo que hemos visto es, en realidad, la novela que escribió Montovani después de viajar a Salas. En este senti-

veronicanietofoco@gmail.com 
do, la película adopta las técnicas narrativas propias de la literatura y hace un juego metaficcional muy interesante. La película funciona como espejo de la novela, y a la vez, se nos cuenta el making off de la novela al tiempo que se nos muestra.

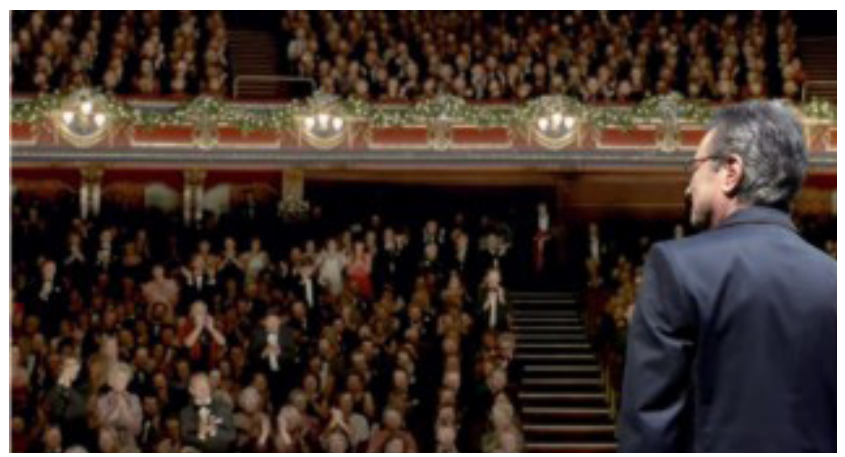

Lo cierto es que en Salas la cosa se va convirtiendo en un fenómeno fanático. Se trata de un pueblo pequeño, toda la gente se conoce y se saluda por la calle. Montovani hace años que vive en Barcelona y se siente bastante extranjero. Posiblemente creía, como todo escritor, que podría darse una vuelta por allí como si fuese invisible, observarlo todo desde el anonimato, aprovechar la experiencia para transformarla en ficción y marcharse sin implicaciones de ningún tipo. Pero los habitantes de Salas le dan la bienvenida paseándolo en un camión de bomberos como si fuese, él solo, la selección de fútbol; quieren sacarse selfies con él; lo paran en la calle para invitarlo a comer a sus casas; una atractiva jovencita lo visita en su hotel y lo seduce. Sin embargo, el entusiasmo inicial se va convirtiendo, poco a poco, en requerimientos de todo tipo. Como si Montovani fuese responsable de algo. El ambiente se va enrareciendo a pasos agigantados: de adorarlo pasan a recelar de él y, al día siguiente, comienzan a odiarlo. Por si fuera poco, los matones del pueblo están en contra de su opinión con respecto a quién tiene que ganar el concurso de pintura, y lo atacan con intimidaciones y una campaña de desprestigio. Tal vez el punto álgido de esta escalada de deshumanización se percibe en la escena del hombre que tiene un hijo en silla de ruedas. El hombre le pide que le compre una. En ese momento, Montovani le dice que si accede a comprar la silla, sería como un Dios, un Salvador. Sigmund Freud (1921), en Psicología de las masas y análisis del yo dijo que el fanatismo es una especie de hipnosis similar al enamoramiento:

La masa es extraordinariamente influenciable y crédula; es acrítica, lo improbable no existe para ella. Piensa por imágenes que se evocan asociativamente unas a otras, tal como sobrevienen al individuo en los estados del libre fantaseo; ninguna instancia racional mide su acuerdo con la realidad. Los sentimientos de la masa son siempre muy simples y exaltados. Por eso no conoce la duda ni la incerteza. Pasa pronto a los extremos, la sospech a formulada se le convierte enseguida en certidumbre incontrastable, un germen de antipatía deviene odio salvaje. (p. 74).

\section{O citemos a Elias Canetti (1960) en Masa y poder:}

Entre los rasgos más llamativos en la vida de la masa, hay uno que podriamos designar con el nombre de 'sentimiento de persecución', una peculiar y furiosa sensibilidad e irritabilidad frente a los enemigos señalados como tales de una vez para siempre. Ya pueden estos emprender lo que se les antoje, proceder con rigidez o condescendencia, ser comprensivos o fríos, duros o blandos: todo en ellos se interpretará como si brotase de una inconmovible malignidad, de una mala disposición para con la masa, de una intención preconcebida de destruirla abierta o alevosamente. (p. 14)

La masa desconoce el razonamiento propio del individuo. Odia o ama con absoluta intensidad y sin motivos. La masa no quiere pensar, la masa o bien lincha, o bien quiere ser fan. Detengámonos un momento en el fenómeno de la literatura. Recordemos que tanto quien lee como quien escribe está solo y, por lo tanto, mientras lo está haciendo no existe la posibilidad del dejarse llevar propio de la masa. Uno podría afirmar que la literatura es contraria a cualquier fenómeno de masas, pero hoy en día el foco se ha desplazado del texto hacia el escritor de carne y hueso. Porque la gente no lee novelas, tan solo quiere conocer a los escritores y llevarse un ejemplar con su firma. Las editoriales y las librerías organizan eventos mediáticos porque saben perfectamente que la gente comprará el libro tan solo porque allí estará presente el autor, podrán hacerse una selfie con él, les dibujará un garabato en la portadilla, algo que parece especialmente dirigido a ti, querido lector, pero que, salvo por el nombre de la dedicatoria, será idéntico a todos los que están esperando en la fila. No importa si ese ejemplar es leído o no después. Si Maurice Blanchot (1955), en su ya célebre El espacio literario, dijo que el autor había muerto y vaticinó un futuro literario donde los textos se sostendrían por sí solos, se equivocó de lleno: el autor es lo único que importa hoy cuando hablamos de literatura.

\section{Función del autor, función del lector}

Pero vayamos por partes. A partir del formalismo ruso y del estructuralismo francés, la crítica literaria dejó de centrarse en la biografía del autor e incluso en una crítica psicoanalítica de la obra para prestar atención a cuestiones de estructura del texto: el texto funciona solo, 
no necesita del respaldo del autor para ser comprendido. El autor de carne y hueso deja de tener importancia y se habla del autor como una función y como un estilo. Es decir, el autor está también dentro del texto con sus rasgos propios de escritura, con su musicalidad, sus recurrencias semánticas, sus preferencias temáticas y, sobre todo, con su estilística. Que la persona que escribe lo haya hecho en el campo, estando enamorado, después de un accidente o siendo sudamericano, apenas importa para la literatura. Que se haya casado con tal persona o haya tenido un affaire con aquella otra, menos aún. A la literatura le sirven de poco estos detalles biográficos, así como la intención del autor: el hecho literario sigue ejecutándose mientras exista un texto y un lector.

Maurice Blanchot no solo había matado al autor, sino que había asegurado que este era incapaz de leerse a sí mismo. El escritor no podía llegar a comprender del todo eso que había escrito. Aunque tuviera una intención concreta a la hora de escribirlo, el texto terminaba por significar cosas insospechadas por él mismo, como si eso que escribió fuera un ente independiente, como si cobrara vida propia y se le escapara de las manos. Era el lector quien al final terminaba por construir la obra en el acto mismo de leerla, interpretarla y otorgarle sentido.

De modo que el foco de atención fue dirigiéndose hacia el lector, pues es el lector quien verdaderamente termina por dar sentido al texto. No importa tanto quién lo escribió, sino quién lo está leyendo, pues la interpretación de cada cual es la que se encarga de otorgar sentido. No existe una sola interpretación correcta, que tradicionalmente se atribuía a la intencionalidad de ese autor de carne y hueso, sino que hay tantas interpretaciones posibles como lectores.

Así nació la teoría de la recepción. Cada lector interpretará una obra de modo diferente, la leerá a su manera. Mientras más creativo e imaginativo sea el lector, mientras más lecturas acumule y mayor sea su capacidad interpretativa, mejor parada saldrá la obra. Diríase que la obra crece a medida que goza de mejores lectores. Piénsese en aquel cuento de Jorge Luis Borges, "Pierre Menard, autor del Quijote". En este cuento, incluido en el libro Ficciones (Borges, 1944), el tal Pierre Menard intenta volver a escribir el Quijote. Para eso, procura imitar la vida de Cervantes de tal forma que, copiando detalle a detalle cada mínimo gesto de su biografía, surja naturalmente la misma literatura. Y lo consigue. Lo que pasa es que, aunque el Quijote de Pierre Menard sea idéntico al de Cervantes, palabra por palabra, el significado ha cambiado rotundamente: ambos Quijotes significan cosas distintas en cada momento histórico. La época cambia el sentido, pues son la lectura y la interpretación las que otorgan significado.

Para leer no necesitamos conocer a la persona que está detrás de esa máscara llamada autor, apenas importa en realidad. La literatura en sí no necesita del autor de carne y hueso, y esto está más que comprobado en los casos de los textos firmados por pseudónimos y más todavía en los textos anónimos, pues aunque no tengamos ni idea de quién es su autor, siguen funcionando perfectamente. De nada sirve, salvo como datos anecdóticos, conocer al dedillo la biografía del autor, las motivaciones de su escritura, si sufría o era feliz en el momento de sentarse a escribir. Además, la ficción lo tergiversa todo. Ni siquiera ante una autobiografía podemos estar seguros de que se está siendo absolutamente fiel a la verdad. Porque cuando se pone en juego la escritura, siempre se activa a su vez la primacía de lo tergiversado, la manipulación a conveniencia del texto, incluso en los casos de textos biográficos.

\section{El autor como estrella mediática}

Pero la gente no quiere leer, la gente quiere ser fan. El fenómeno de recepción de una obra ha ido prestando cada vez más atención a la figura del escritor: a la gente le interesa más el autor de carne y hueso que su literatura. En realidad, apenas importa la literatura. El autor no solo está más vivo que nunca, sino que tampoco importa aquello que produce. Esas diferencias entre el autor de carne y hueso y la función-autor dentro del texto (el estilo-autor) carecen de sentido para la mayoría. En la época mediática en la que estamos inmersos, es más valioso ser amigo del escritor que haber leído sus textos. Es más interesante seguir sus pasos en las redes sociales que conocer sus novelas. Vale más un autógrafo y una selfie que identificar un estilo o que llevar a cabo una lectura inteligente. Piénsese en el caso del escritor de la película que nos ocupa: solo importa su figura, si va o no a cenar a la casa de tal o cual vecino de Salas, quién era su noviecita de la infancia, cuáles eran las cuitas con su mejor amigo. La gente lo quiere solo porque es famoso, no por lo que escribe. De hecho, apenas nadie ha leído sus libros y a nadie le importa en realidad. A este respecto, hay una secuencia en la película que resulta esclarecedora: Después de buscar a Montovani en el aeropuerto para llevarlo a Salas, el taxista toma una ruta alternativa arguyendo que así llegarán más rápido. Pero pinchan una rueda y tie- 
nen que pasar la noche en pleno campo. Montovani va arrancando las páginas de su último libro para encender una fogata. Por la mañana, el taxista arranca otra página para utilizarla como papel higiénico. Una vez que llegan al pueblo, Montovani se reúne con el alcalde de Salas y le regala ese mismo ejemplar al que le faltan un montón de páginas. Sabe perfectamente que jamás va a leerlo.

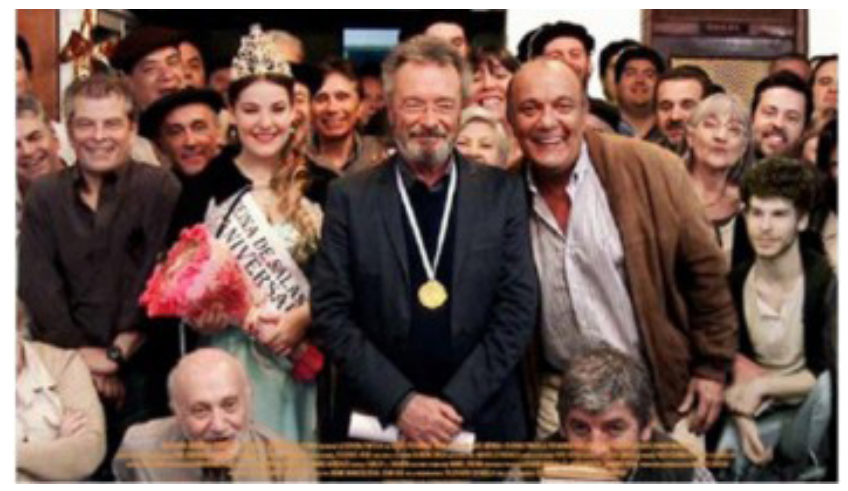

\section{La ficción como verosimilitud}

Pero aparte del fenómeno fan en el arte, que El ciudadano ilustre expone con mucho sentido del humor, se escenifica otro hecho curioso: nadie comprende en qué consiste la literatura. La literatura es la reformulación de la realidad. Puede tomar todos los aspectos biográficos que necesite, pero la ficción siempre se los lleva a su terreno. Los habitantes de Salas confunden a los personajes de las novelas de Montovani con personas reales del pueblo. Montovani dice que pudo haberse inspirado en ciertos vecinos, pero que al final es la novela quien sigue sus propias leyes, es la novela la que toma las decisiones narrativas, la que manda. La fic- ción siempre manipula y tergiversa a su favor, porque siempre gana la narrativa para un escritor. Esto quiere decir que si un texto necesita un asesinato, tendrá un asesinato, no importa si se ajusta o no a la verdad. $\mathrm{Al}$ arte le importa la verosimilitud, no le importa la verdad. Tampoco importa al final lo que pretendía hacer el autor. Como dice Montovani cuando están eligiendo los cuadros del concurso: "Qué importa lo que el artista haya querido hacer”. Importa cómo se lea su obra, cómo se interprete. Por eso es fundamental que contemos con buenos lectores, lectores creativos, que sean capaces de ampliar horizontes. Por eso importa tanto que contemos con lectores inteligentes que construyan sentido, distintas capas de significado, de tal manera que la obra se enriquezca y tome forma mediante la unión de objeto e interpretación. Así, autor y receptor son las dos entidades que hacen posible el hecho artístico, que le otorgan sentido, un sentido que va cambiando, que crece y se amplía, que se enriquece.

Si uno piensa en las grandes obras de todos los tiempos, se da cuenta de que perduran aquellas que siguen interpelando a sus lectores aunque pase el tiempo y se lean en épocas distintas. Esas obras siguen despertando reflexiones y emociones diferentes y van ampliando y enriqueciendo las capas de sentido de la obra en cuestión. Por lo demás, un escritor es ante todo un lector, pero uno muy productivo: quien escribe está leyendo, está engordando y reformulando la tradición. Está conversando con ella, dándole la vuelta, hilando fino. Como decía Ricardo Piglia (2015) en su artículo El escritor como lector: "La literatura es un modo de leer" (p. 91). O citemos también La literatura y la vida (Piglia, 1896): "La inspiración se construye a partir de lo que se ha escrito antes, cada vez se escribe con toda la literatura" (p. 115).

\section{Referencias}

Blanchot, Maurice (1955 [1992]). El espacio literario. Traducción de Vicky Palant y Jorge Jinkis. Barcelona: Paidós.

Borges, Jorge Luis (1944 [1992]). “Pierre Menard, autor del Quijote”. Ficciones. Barcelona: Círculo de Lectores.

Canetti, Elias (1960 [2002]). Masa y poder. Obras Completas. Traducción de Juan José del Solar. Barcelona: Galaxia Gutenberg.

Freud, Sigmund (1921 [1976]). Psicología de las masas y análisis del yo. Obras Completas. Traducción de José L. Etcheverry. Buenos Aires: Amorrortu.

Piglia, Ricardo (1986 [2001]). “La literatura y la vida”. Crítica y ficción. Barcelona: Anagrama.

Piglia, Ricardo (2015). “El escritor como lector”. Antología personal. Barcelona: Anagrama. 